\title{
The Solar Cell Parameters as a Function of Its Temperature in Relation to Its Diurnal Efficiency
}

\author{
Samia Sayed Mustafa Shaban \\ Physics Department, Faculty of Education, Aim Shams University, Heliopolis, Cairo, Egypt \\ Email: samiasayed@edu.asu.edu.eg
}

How to cite this paper: Shaban, S.S.M. (2020) The Solar Cell Parameters as a Function of Its Temperature in Relation to Its Diurnal Efficiency. Optics and Photonics Journal, 10, 1-12.

https://doi.org/10.4236/opj.2020.101001

Received: December 15, 2019

Accepted: January 18, 2020

Published: January 21, 2020

Copyright (๑) 2020 by author(s) and Scientific Research Publishing Inc. This work is licensed under the Creative Commons Attribution International License (CC BY 4.0).

http://creativecommons.org/licenses/by/4.0/

\section{(c) (i) Open Access}

\begin{abstract}
The variation of the temperature of the solar cell subjected to the incident global solar radiation along the local daytime in relation to its efficiency is studied. The heat balance equation is solved. The solution revealed that the cell temperature is a function of the maximum value of the daily incident global solar radiation $q_{\max }$, the convection heat transfer coefficient $(h)$, the optical, physical and the geometrical parameters of the cell. The temperature dependence of the short circuit current $I_{s c}$ the dark saturation current $I_{o}$, the open circuit voltage $V_{o c}$ and the energy band gap $E_{g}$ characterizing a Silicon solar cell is considered in evaluating the cell efficiency. Computations of the efficiency concerning operating conditions and astronomical locations (Egypt) as illustrative examples are given.
\end{abstract}

\section{Keywords}

Solar Cell Performance, Solar Energy, Solar Cell Temperature,

Heat Transfer Model

\section{Introduction}

Heating a solar cell subjected to the incident global solar radiation affects its photovoltaic performance [1]-[7]. The solar $\mathrm{p}-\mathrm{n}$ cell is a semiconductor photovoltaic device.

Solar energy can be converted into electricity are termed as the photovoltaic devices or solar cells. At present this solar cell is the most important long-duration power supply for satellites and space vehicles. Solar cells have also been successfully employed in small-scale terrestrial applications. Due to this the study of the efficiency of the solar cell with the aim to increase its value has aroused the in- 
terest of many investigators [8]-[22].

The efficiency $(\eta)$ is a measure of the cell performance which depends on many parameters. Many of such parameters are temperature dependent.

The performance of a solar cell is determined by parameters as a short circuit current $I_{s c}(T)$ and open circuit voltage $V_{o c}(T)$. It has been shown earlier that $I_{s c}$ increases with increasing the temperature whereas open circuit voltage $V_{o c}$ decreases with increasing the temperature.

The aim of the present work is to find theoretically the temperature field within the solar cell considering different optical, physical, geometrical conditions. The temperature functional dependences of the cell parameters $V_{o c} I_{s c}$ and the efficiency are also taken into consideration.

\section{The Mathematical Formulation of the Problem}

In sitting up the problem it is assumed that solar radiation of irradiance $q(t)$ $\mathrm{W} / \mathrm{m}^{2}$ is incident on the front surface of the solar cell, where it is partly absorbed and partly reflected.

The absorbed quantity is $A q(t)$, where " $A$ " is the absorption coefficient at the front surface of the considered cell. The heat diffusion equation is given in the form:

$$
S A_{a b} q(t)-\operatorname{Sh} \theta(t)=S \rho l c_{p} \frac{\mathrm{d} \theta}{\mathrm{d} t}
$$

where:

$\theta(t)=\left(T(t)-T_{O}\right), \mathrm{K}$ is the excess temperature of the cell relative to the ambient temperature $T_{O}, S\left(\mathrm{~m}^{2}\right)$ is the area of the cell front surface, $h\left(\mathrm{~W} / \mathrm{m}^{2} \cdot \mathrm{K}\right)$ is the convection heat transfer coefficient at the front surface, $I(\mathrm{~m})$ is the all layer thickness, $\rho\left(\mathrm{kg} / \mathrm{m}^{3}\right), c_{p}(\mathrm{~J} / \mathrm{kg} \cdot \mathrm{K})$ are density and the specific heat of the solar cell material respectively.

Equation (1) can be written as:

$$
\frac{\mathrm{d} \theta}{\mathrm{d} t}+a \theta(t)=B q(t)
$$

where,

$$
a=\frac{h}{\rho l c_{p}} \text { and } B=\frac{A}{\rho l c_{p}}
$$

Equation (2) can be solved using the integrating factor [23] as follows:

$$
\theta(t) \mathrm{e}^{\int_{0}^{t} a d t}=\int_{0}^{t} B q(t) \mathrm{e}^{\int_{0}^{t} a d t}
$$

$q(t),\left(\mathrm{W} / \mathrm{m}^{2}\right)$ is the irradiance of the incident solar radiation given in the form [24]:

$$
q(t)=q_{\max }\left(\frac{1}{t_{0}}\right)^{2}\left(\frac{1}{t_{d}-t_{0}}\right)^{2} t^{2}\left(t_{d}-t\right)
$$

where: 
$q_{\max }, \mathrm{W} / \mathrm{m}^{2}$ is the maximum irradiance of the incident solar radiation;

$t_{0}=\left(t_{d} / 2\right)$, is the mid time between sunrise and sunset in hours;

$t_{d}=\left(t_{s}-t_{r}\right)$, is the length of the solar day given as:

$$
t_{d}=\frac{2}{15} \cos (-\tan \phi \tan \delta)
$$

where:

$\phi$, is the latitude and $\delta$ is the solar declination angle given as:

$$
\delta=23.45 \sin \frac{284+n}{365}
$$

$t_{r}$, is the sunrise time in hours;

$t_{s}$, is the sunset time in hours;

And " $n$ " is the day of the year $(1 \leq n \leq 365)$ starting from 1 January.

The solution is obtained as the form [26]:

$$
\begin{aligned}
\theta(t)= & B t_{d}^{2}\left[\left(\frac{t^{2}}{a}-\frac{2 t}{a^{2}}+\frac{2}{a^{3}}\right)-\frac{2}{a^{3}} \mathrm{e}^{-a t}\right]-2 B t_{d}\left[\left(\frac{t^{3}}{a}-\frac{3 t^{2}}{a^{2}}+\frac{6 t}{a^{3}}-\frac{6}{a^{4}}\right)+\frac{6}{a^{4}} \mathrm{e}^{-a t}\right]_{(5)} \\
& +B\left[\left(\frac{t^{4}}{a}-\frac{4 t^{3}}{a^{2}}+\frac{12 t^{2}}{a^{3}}-\frac{24 t}{a^{4}}+\frac{24}{a^{5}}\right)-\frac{24}{a^{5}} \mathrm{e}^{-a t}\right]
\end{aligned}
$$

Equation (5) represents the temperature of the considering cell after an exposure time " $t$ " along the solar day time.

\section{The Efficiency Temperature Dependence for the Solar Cell}

The efficiency $(\eta)$ of the solar cell is defined as the ratio between the maximum power $P_{\max }\left(=F F V_{o c} I_{s c}\right)$, generated by a solar cell and the received power $P_{\text {in }}$ as follows [2]:

$$
\eta=\frac{F F I_{s c} V_{o c}}{P_{\text {in }}}
$$

$P_{\text {in }}\left(\mathrm{W} / \mathrm{m}^{2}\right)$ is the input total solar power received by the solar cell;

$V_{o c}$ is the open circuit voltage which is given as [2]:

$$
V_{o c}=\frac{K T}{e} \ln \left(\frac{I_{s c}}{I_{o}}+1\right)
$$

where:

$K(\mathrm{~J} / \mathrm{K})$ is the Boltzmann constant, $T(\mathrm{~K})$ is the cell temperature $(e=1.6 \times$ $10^{-19}$ Coulomb) is the electron charge, $I_{o}\left(\mathrm{amp} / \mathrm{m}^{3}\right)$ is the reverse saturation current and its dependence on temperature is revealed through the following equation [2]:

$$
I_{o}=\epsilon n T^{\gamma} \mathrm{e}^{\frac{-E_{g}}{K T}}
$$

where:

$\epsilon=179 \mathrm{amp} / \mathrm{K}^{3} \cdot \mathrm{m}^{2}$ for silicon solar cell [18], $n$ is non-ideality factor of the cell and is taken as unity, the value of $\gamma=3$ [2];

$E_{g}$ is the energy band gap. The dependence of energy band gap of a semicon- 
ductor on temperature can be described as [27] [28]:

$$
E_{g}=E_{g}(0)-\frac{\alpha T^{2}}{T+\beta}
$$

$E_{g}(0)$ is the energy band gap of the semiconductor at $T \approx 0 \mathrm{~K}$;

For silicon $E_{g}(0)=1.16 \mathrm{eV}$ [29], $\alpha=7 \times 10^{-14} \mathrm{eV} \cdot \mathrm{K}^{-1}$ and $\beta=1100 \mathrm{~K}$.

Which are constants for each semiconductor material [28], $I_{s c}$ is short circuit current given as [8],

$$
I_{S C}=Q(1-R(T))(1-\operatorname{expel}(\mu l)) e n_{\text {photons }}
$$

where:

$Q$ is the collection factor, $R(T)$ is the reflection coefficient at the front face of the cell and its value is given as [30]:

$$
R(T)=0.322+3.12 \times 10^{-5} T
$$

$\mu$ is the attenuation coefficient and is value given as [30]:

$$
\mu=a \exp \left(T / T_{S}\right)
$$

where:

$$
a=3.17 \times 10^{4} \mathrm{~m}^{-1} \text {; and }
$$

$T_{S}=346 \mathrm{~K}, l$ in meter is the thickness of the solar cell,

$n_{\text {photons }}$ is the number of photons with energy greater than the band gap and for simplicity its value for a given temperature $T$ at a certain local daytime is given as:

$$
n_{\text {photon }}=q(t) / E_{g}
$$

\section{Computations}

The silicon solar cell is considered with dimensions $(5.5 \mathrm{~cm} \times 11 \mathrm{~cm} \times 0.35 \mathrm{~cm})$ is considered [31]. The silicon solar cell temperature as a function of the local day time " $t$ " is calculated using Equation (5), the physical parameters of Silicon are:

$$
\rho=2280 \mathrm{~kg} / \mathrm{m}^{3}, c_{p}=840 \mathrm{~J} / \mathrm{kg}
$$

The hourly incident global solar radiation $q(t)$ (Equation (4)) is considered for Egypt [32] as an illustrative example. The values of $I_{s c} I_{o}$, and $V_{\text {oc }}$ corresponding to each value of $T$ at a certain time " $t$ " are determined.

Hence the efficiency " $\eta$ " of the cell as a function of the solar local day time " $t$ " is estimated for considered location.

For Egypt (July) [32] the $q(t)$ parameters are:

$q_{\max }=1045 \mathrm{~W} / \mathrm{m}^{2}, t_{d}=14$ hours, $t_{r}=0$ hours, $t_{0}=7$ hours.

Different thickness $l=10^{-3}, 3 \times 10^{-3}, 5 \times 10^{-3} \mathrm{~m}$ are considered at $h=1$ $\mathrm{W} / \mathrm{m}^{2} \cdot \mathrm{K}, A=0.7$.

The obtained results are given in Table 1 and illustrated graphically in Figure 1 showing that the temperature of the solar cell increases as the thickness decreases.

Different cooling conditions $h=3,5,10 \mathrm{~W} / \mathrm{m}^{2} \cdot \mathrm{K}$ are considered at thickness $l=$ $10^{-3} \mathrm{~m}, A=0.7$ the obtained results are given in Table 2 and illustrated graphically 
Table 1. The temperature of the cell as a function of the local day time at $A=0.7$ and $h=$ $1 \mathrm{~W} / \mathrm{m}^{2} \cdot \mathrm{K}$ for different value of the thickness.

\begin{tabular}{|c|c|c|c|}
\hline \multirow{2}{*}{$\begin{array}{l}\text { shifted time } \\
\qquad t, \mathrm{hr} .\end{array}$} & \multicolumn{3}{|c|}{$T, K$} \\
\hline & $I=10^{-3} \mathrm{~m}$ & $1=3 \times 10^{-3} \mathrm{~m}$ & $I=5 \times 10^{-3} \mathrm{~m}$ \\
\hline 0 & 0 & 0 & 0 \\
\hline 1 & 21.5 & 0 & 6.4 \\
\hline 2 & 111 & 11.7 & 40.1 \\
\hline 3 & 250 & 106 & 108 \\
\hline 4 & 405 & 230 & 205 \\
\hline 5 & 548 & 363 & 316 \\
\hline 6 & 656 & 483 & 426 \\
\hline 7 & 714 & 573 & 520 \\
\hline 8 & 716 & 620 & 583 \\
\hline 9 & 660 & 617 & 608 \\
\hline 10 & 554 & 563 & 591 \\
\hline 11 & 412 & 467 & 534 \\
\hline 12 & 257 & 341 & 445 \\
\hline 13 & 116 & 208 & 339 \\
\hline 14 & 26.5 & 96.4 & 239 \\
\hline
\end{tabular}

Table 2. The temperature of the cell as a function of the local day time at $l=10^{-3} \mathrm{~m}$ and $A$ $=0.7$ for different value of the cooling.

\begin{tabular}{cccc}
\hline \multirow{2}{*}{$\begin{array}{c}\text { shifted time } \\
\boldsymbol{t} \text { hr. }\end{array}$} & \multicolumn{3}{c}{$\boldsymbol{T}, \boldsymbol{K}$} \\
\cline { 2 - 4 } $\mathbf{h}\left(\mathrm{W} / \mathrm{m}^{2} \cdot \mathrm{K}\right)$ & $\boldsymbol{h}=\mathbf{5}\left(\mathrm{W} / \mathrm{m}^{2} \cdot \mathrm{K}\right)$ & $\boldsymbol{h}=\mathbf{1 0}\left(\mathrm{W} / \mathrm{m}^{2} \cdot \mathrm{K}\right)$ \\
\hline 1 & 0 & 0 & 0 \\
2 & 12.3 & 8.44 & 4.52 \\
3 & 50.1 & 32 & 16.2 \\
4 & 101 & 62.9 & 31.1 \\
5 & 153 & 94.2 & 45.7 \\
6 & 198 & 121 & 57.6 \\
7 & 229 & 139 & 64.9 \\
8 & 242 & 146 & 66.4 \\
9 & 236 & 141 & 61.7 \\
10 & 211 & 126 & 51.2 \\
11 & 170 & 100 & 35.9 \\
12 & 120 & 69.7 & 17.5 \\
13 & 67.2 & 38.2 & 0 \\
14 & 23.4 & 12.5 & 0 \\
\hline
\end{tabular}




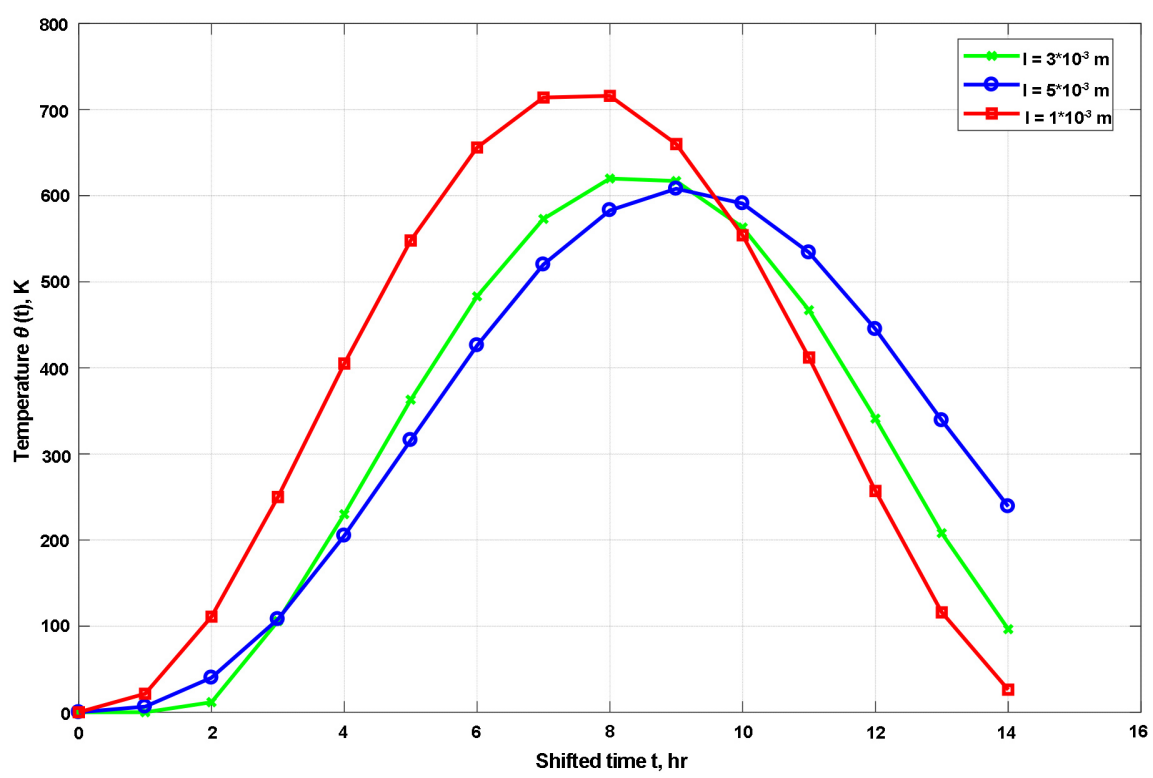

Figure 1. The variation of the temperature of the cell as a function of the local day time in $h=1 \mathrm{~W} / \mathrm{m}^{2} \cdot \mathrm{K}$ and $A=0.7$ for different thickness.

in Figure 2 which show that the temperature of the solar cell increases as the cooling conditions at the front surface decreases.

Different absorption coefficients $A=0.6,0.7,0.8$ are considered at $l=10^{-3} \mathrm{~m}$, $h=3 \mathrm{~W} / \mathrm{m}^{2} \cdot \mathrm{K}$. The obtained results are given in Table 3 and illustrated graphically in Figure 3 which show that the temperature of the solar cell increases as the absorption coefficients at the front surface increases.

The variation of $I_{s c}, V_{o c}$ for the case:

$I=5 \times 10^{-3} \mathrm{~m}, A=0.7, h=1 \mathrm{~W} / \mathrm{m}^{2} \cdot \mathrm{K}$ are computed and are illustrated in Figure 4 and Figure 5.

The obtained results revealed that $I_{s c}$ increases with increasing the temperature and vic versa.

Moreover, the dependence of the efficiency of the considered solar cell on the thickness 1 , are clarified.

The efficiency at: $h=1 \mathrm{~W} / \mathrm{m}^{2} \cdot \mathrm{K}, A=0.7$ and thickness $l=10^{-3}, 3 \times 10^{-3}, 5 \times$ $10^{-3} \mathrm{~m}$ is computed and is illustrated in Figures 6-8.

\section{Results and Discussions}

The obtained results reveal that: The cell temperature decreases as the transfer coefficient for cooling increases, also it decreases as the thickness of the cell increases while it increases as the absorption coefficient " $A$ " at its front surface increases. This is because when " $A$ " increases the value of the solar power absorbed by the cell increases.

Moreover, the short circuit current $I_{s c}$ increases with increasing temperature and vice versa. This variation may be attributed to the fact that for most semi-conductors, as the temperature increases, the energy band gab decreases [19]. 


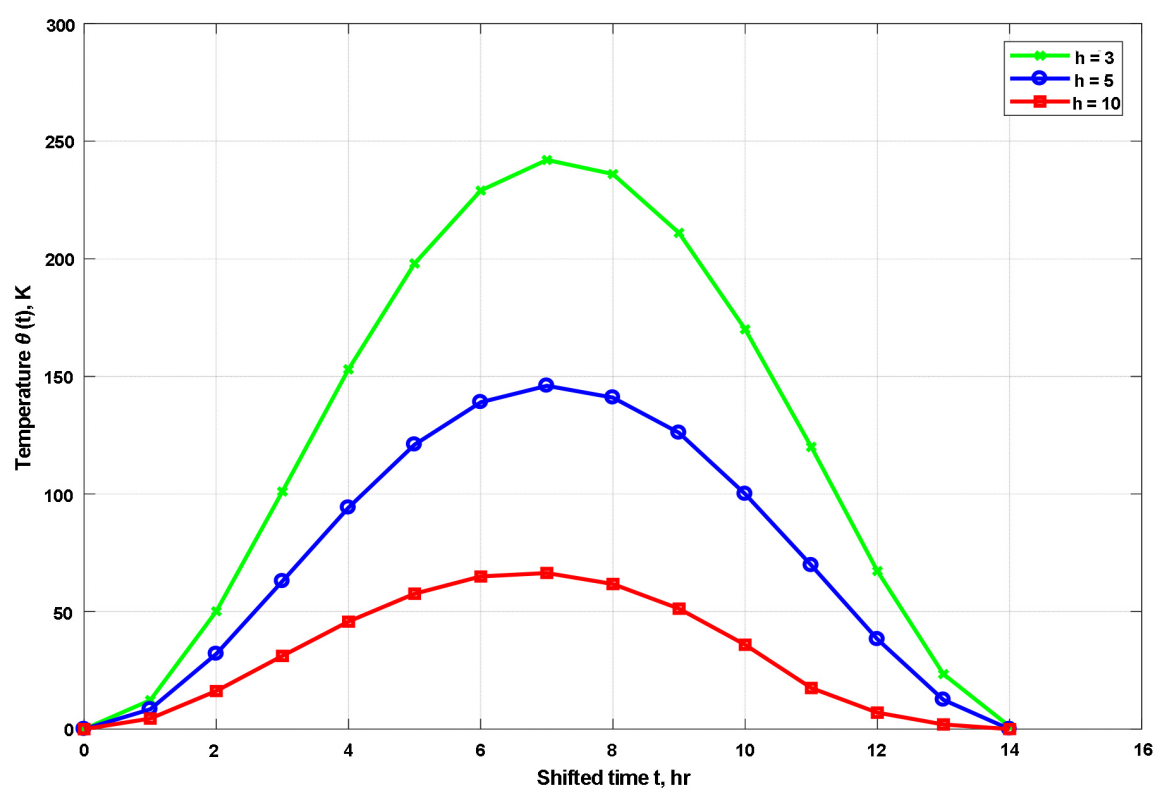

Figure 2. The variation of the temperature of the cell as a function of the local day time in $l=10^{-3} \mathrm{~m}$ and $A=0.7$ for different values of the cooling coefficient.

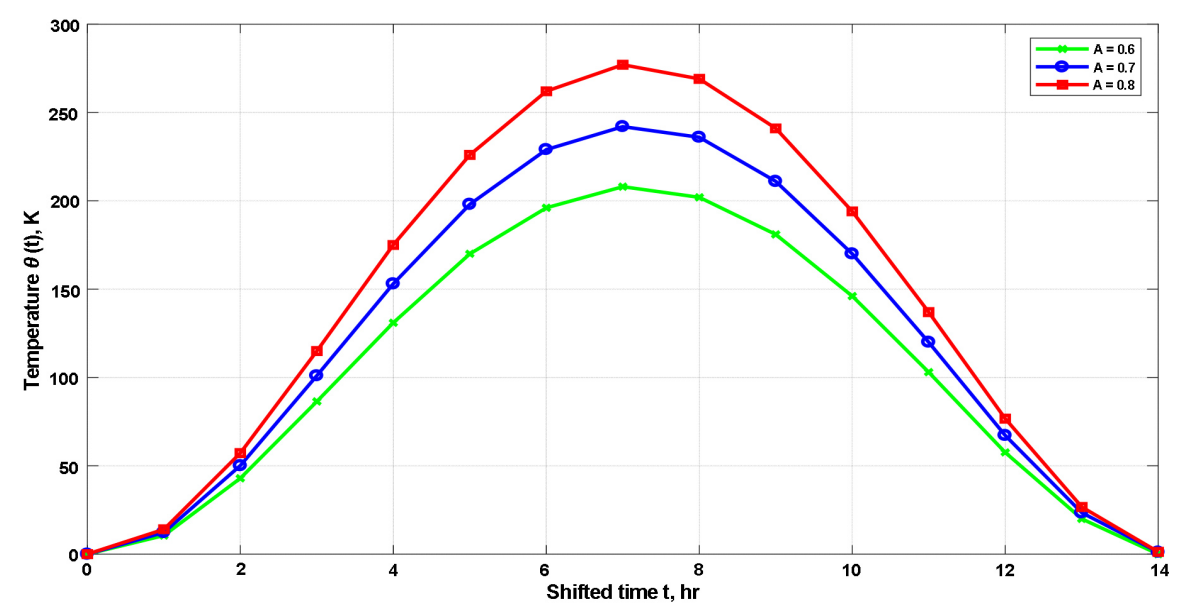

Figure 3. The variation of the temperature of the cell as a function of the local day time in $l=10^{-6} \mathrm{~m}$ and $A=0.7$ for different values of the cooling coefficient.

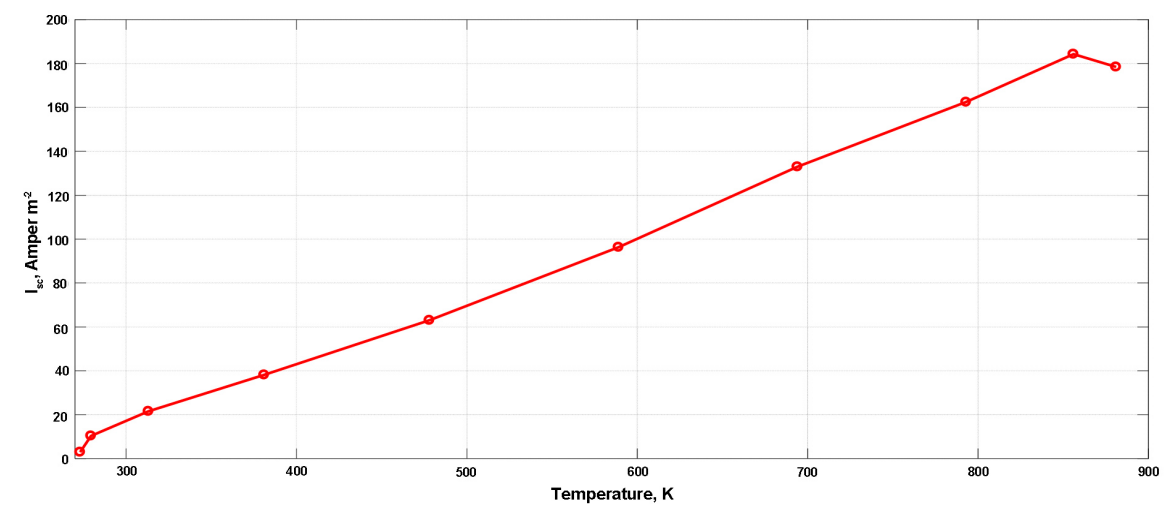

Figure 4. The variation of $I_{s c}$ at $l=5 \times 10^{-3} \mathrm{~m}, h=1 \mathrm{~W} / \mathrm{m}^{2}$ and $A=0.7$. 


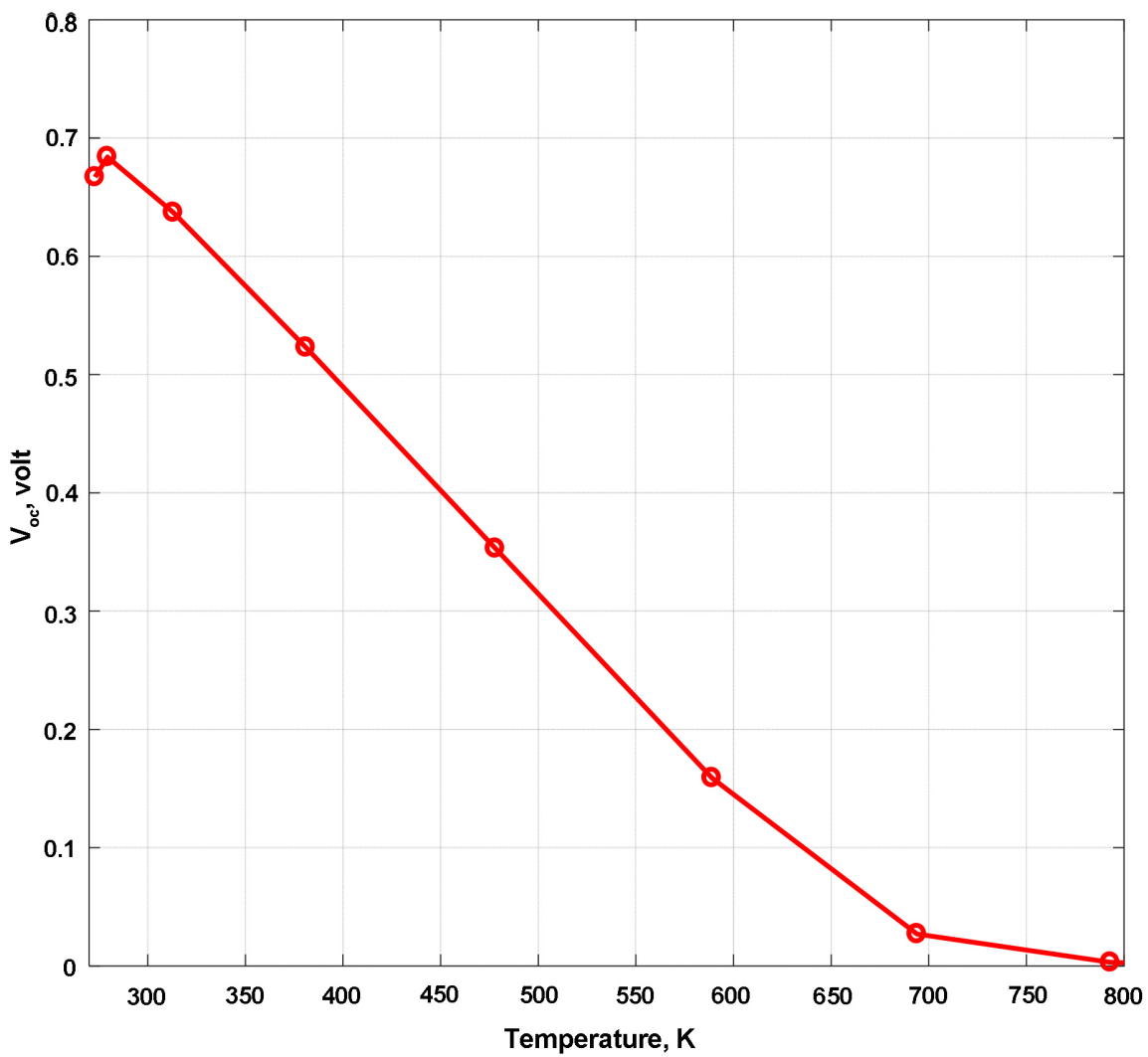

Figure 5. The variation of $V_{o c}$ at $l=5 \times 10^{-3} \mathrm{~m}, h=1 \mathrm{~W} / \mathrm{m}^{2} \cdot \mathrm{K}$ and $A=0.7$.

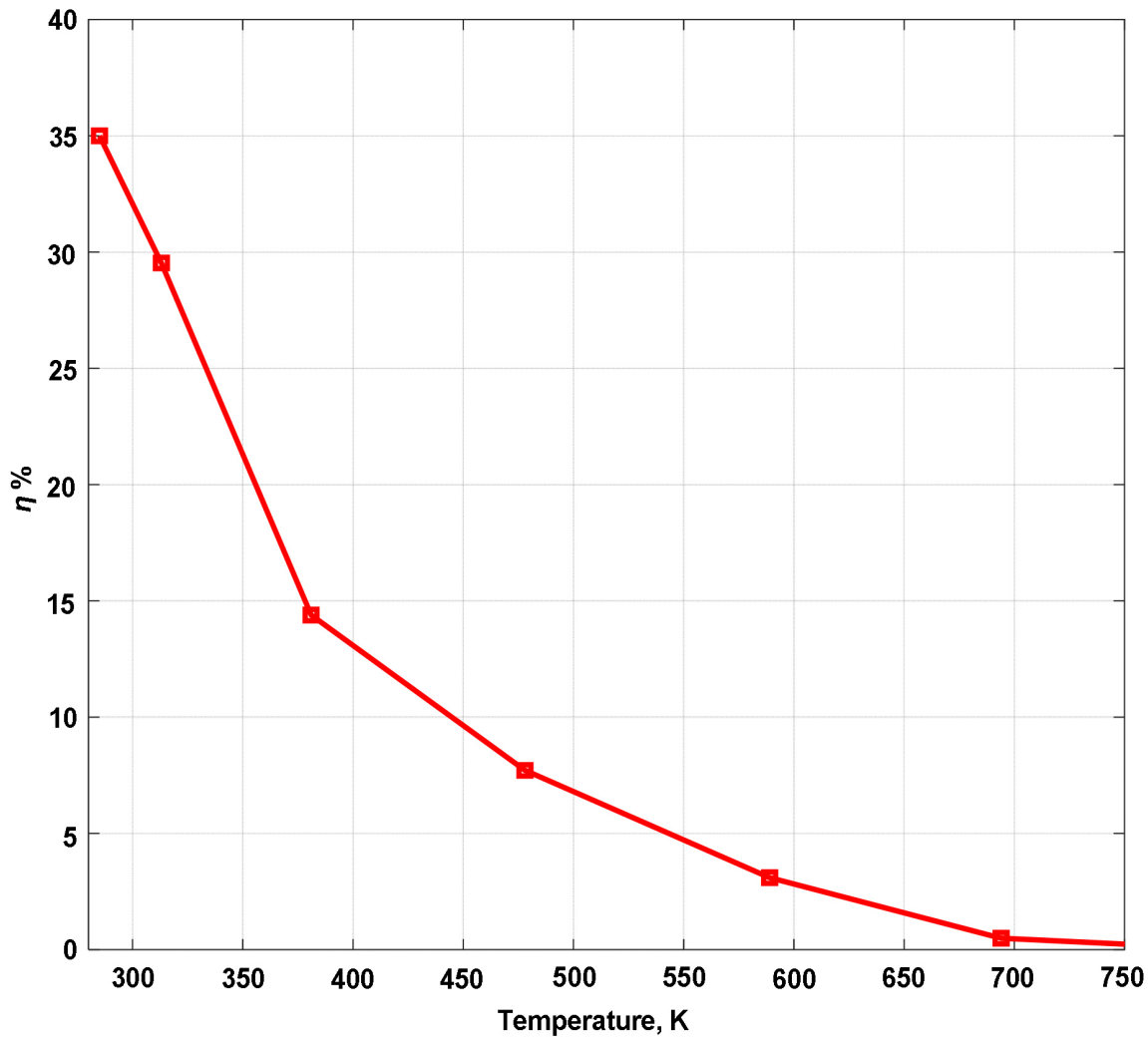

Figure 6. The temperature dependence of $n$ at $l=5 \times 10^{-3} \mathrm{~m}, h=1 \mathrm{~W} / \mathrm{m}^{2} \cdot \mathrm{K}$ and $A=0.7$. 


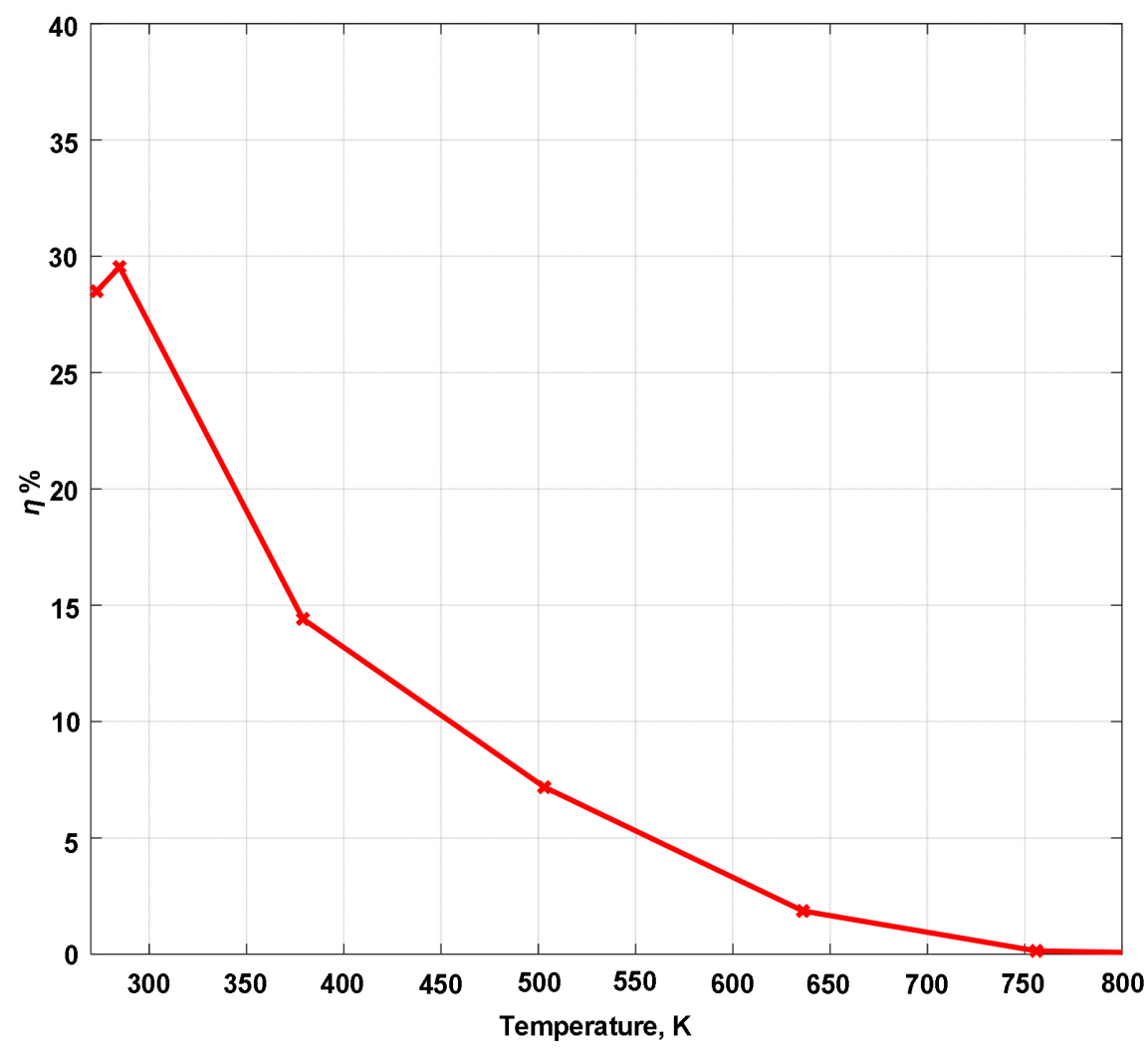

Figure 7. The temperature dependence of $n$ at $l=5 \times 10^{-3} \mathrm{~m}, h=1 \mathrm{~W} / \mathrm{m}^{2} \cdot \mathrm{K}$ and $A=0.7$.

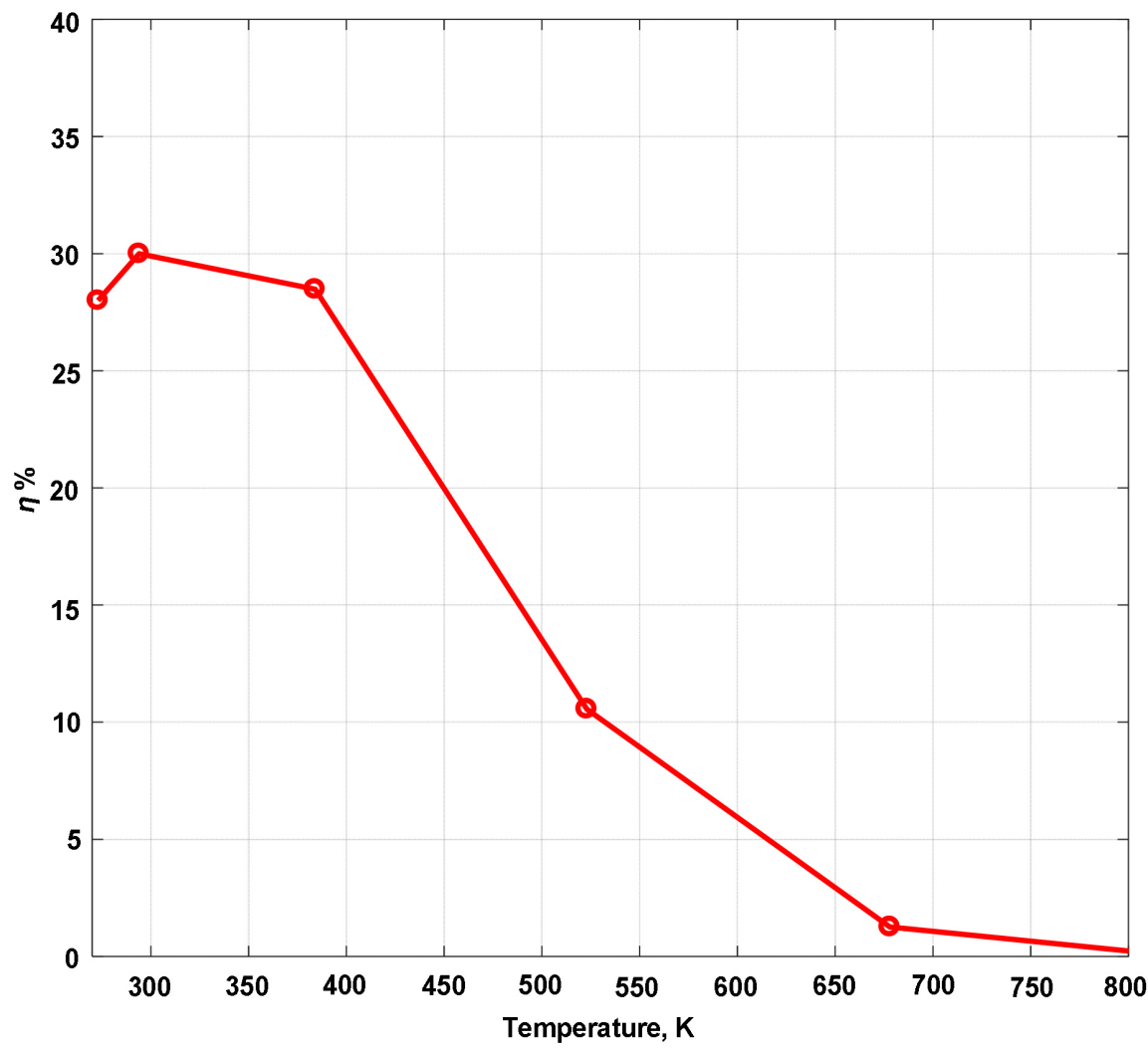

Figure 8. The temperature dependence of $\eta$ at $l=10^{-3} \mathrm{~m}, h=1 \mathrm{~W} / \mathrm{m}^{2} \cdot \mathrm{K}$ and $A=0.7$. 
Table 3. The temperature of the cell as a function of the local day time at $l=10^{-3} \mathrm{~m}$ and $h$ $=3 \mathrm{~W} / \mathrm{m}^{2} \cdot \mathrm{K}$ for different value of the absorption coefficient at the front surface.

\begin{tabular}{|c|c|c|c|}
\hline \multirow{2}{*}{$\begin{array}{l}\text { shifted time } \\
\qquad t, \mathrm{hr} .\end{array}$} & \multicolumn{3}{|c|}{$T, K$} \\
\hline & $A=0.6$ & $A=0.7$ & $A=0.8$ \\
\hline 0 & 0 & 0 & 0 \\
\hline 1 & 10.6 & 12.3 & 14.1 \\
\hline 2 & 42.9 & 50.1 & 57.2 \\
\hline 3 & 86.4 & 101 & 115 \\
\hline 4 & 131 & 153 & 175 \\
\hline 5 & 170 & 198 & 226 \\
\hline 6 & 196 & 229 & 262 \\
\hline 7 & 208 & 242 & 277 \\
\hline 8 & 202 & 236 & 269 \\
\hline 9 & 181 & 211 & 241 \\
\hline 10 & 146 & 170 & 194 \\
\hline 11 & 103 & 120 & 137 \\
\hline 12 & 57.6 & 67.2 & 76.7 \\
\hline 13 & 20 & 43.4 & 26.7 \\
\hline 14 & 0 & 1.15 & 1.31 \\
\hline
\end{tabular}

Equation (7) reveals that the behavior of $V_{o c}$ with temperature is controlled by two factors $\frac{k T}{e}$ and $\ln \left(\frac{I_{s c}}{I_{o}}+1\right)$. The first factor suggests a linear relation on ( $T$ ) while is relation deviated due to the presences of the logarithmic function $\ln \left(\frac{I_{s c}}{I_{o}}\right)$ grows slowly with $T$ than the function $\frac{k T}{e}$.

$V_{o c}$ has weak dependence on " $T$ " than $I_{s c}$

\section{Conclusions}

The temperature of the solar cell subjected to incident solar insolation increases with local day time and passes through a maximum value then it decreases gradually toward sunset. The cell parameters $V_{o c}, I_{s c}$ and the efficiency $\eta$ are functions of the cell temperature with different degrees.

The efficiency $\eta$ of the cell decreases with the cell temperature in general. Thus cooling, the solar cell is recommended.

The open circuit voltage $V_{o c}$ is less dependent on the temperature than the short circuit current $I_{s c}$

\section{Conflicts of Interest}

The author declares no conflicts of interest regarding the publication of this paper. 


\section{References}

[1] Markvart, T. (1994) Solar Electricity. UNESCO Energy Series, Charpter 7, John Wiley \& Sons Ltd., Hoboken.

[2] Green, M.A. (1982) Solar Cells, Operating Principles Technology and System Applications. Prentice-Hall, Inc., Englewood Cliffs.

[3] Stutenaumer, U., Negash, T. and Abdi, A. (1999) Performance of Small Scale Photovoltaic Systems and Their Potentials for Rural Electrification in Ethiopia. Renewable Energy, 18, 35-48. https://doi.org/10.1016/S0960-1481(98)00784-8

[4] El-Adawi, M. and Al-Nuaim, I. (2007) The Temperature Functional Dependence of Voc for a Solar Cell in Relation to Its Efficiency New Approach. Desalination, 209, 91-96. https://doi.org/10.1016/j.desal.2007.04.014

[5] El-Adawi, M. and Al-Shameri, N. (2012) The Efficiency of the Solar Converter as a Function of the Doping Degrees and the Incident Solar Spectral Photon Flux. Canadian Journal on Scientific and Industrial Research, 3, 112-122.

[6] El-Adawi, M. and Al-Shameri, N. (2012) The Efficiency of a p-n Solar Diode as a Function of the Recombination Velocity within the Depletion Layer. Optics and Photonics Journal, 2, 326-331. https://doi.org/10.4236/opj.2012.24040

[7] El-Adawi, M. and Al-Nuaim, I. (2010) The Temperature Variation of a Solar Cell in Relation to Its Performance. Journal of Environmental Science and Engineering, 4, 56-59.

[8] Ysocki, J.J.W. and Rappaport, P. (1960) Effect of Temperature on Photovoltaic Solar Energy Conversation. Journal of Applied Physics, 31, 571-578. https://doi.org/10.1063/1.1735630

[9] Fan, J.C., Tsaur, B. and Palmin, B. (1982) Optimal Design of High Efficiency Tandem Cells. IEEE Photovoltaics Specialists Conference, San Diego, 28 September $1982,692$.

[10] Verlinden, P., Swansons, R. and Crane, R. (1995) 7000 High-Efficiency Cells for a Dream. Progress in Photo Voltaic. Research and Applications, 2, 143-152. https://doi.org/10.1002/pip.4670020209

[11] Wettling, W. (1995) High Efficiency Silicon Solar Cells, State of the Art and Trends. Solar Energy Material and Solar Cells, 38, 487-500. https://doi.org/10.1016/0927-0248(94)00240-1

[12] Bouazzi, A., Abaab, M. and Rezig, B. (1997) A New Model of Very High Efficiency Buried Emitter Silicon Solar Cell. Solar Energy Material and Solar Cells, 46, 29-41. https://doi.org/10.1016/S0927-0248(96)00091-8

[13] Yerokhov, V., Melnyk, I.A. and Korovin, V. (1999) External Bias as the Factor of Efficiency Increase of Silicon MIS/IL Solar Cells. Solar Energy Material and Solar Cells, 58, 225-236. https://doi.org/10.1016/S0927-0248(98)00206-2

[14] Luque, A. and Marti, A. (1999) Limiting Efficiency of Coupled Thermal and Photovoltaic Converters. Solar Energy Material and Solar Cells, 58, 147-165. https://doi.org/10.1016/S0927-0248(98)00199-8

[15] El-Adawi, M.K. and Al-Nuaim, I. (2014) New Approach to Modeling a Solar Cell in Relation to Its Efficiency-Laplace Transform Technique. Optics and Photonic Journal, 4, 219-227. https://doi.org/10.4236/opj.2014.48022

[16] Kittidachan, P., Markvart, T., MBagnall, D., Greef, R. and Ensell, G. (2007) A Detailed Study of p-n Junction Solar Cells by Means of Collection Efficiency. Solar Energy Materials and Solar Cells, 91, 160-166. https://doi.org/10.1016/j.solmat.2006.08.002 
[17] Green, M., Emery, K., Hishikawa, Y. and Warta, W. (2011) Solar Energy Efficiency Tables (Version 37). Progress in Photovoltaic Research and Application, 19, 84-92. https://doi.org/10.1002/pip.1088

[18] Singh, P. and Ravindra, N. (2012) Temperature Dependence of Solar Cell Performance: An Analysis. Solar Energy Materials and Solar Cells, 101, 36-45. https://doi.org/10.1016/j.solmat.2012.02.019

[19] Sze, S. (1981) Physics of Semiconductor Devices. John Wiley \& Sons, New York.

[20] Assim, Q., Al-Naser, H., Mohammed, N., Al-Barghoothi, A. and Al-Ali, N. (2013) The Effect of Temperature Variations on Solar Cell Efficiency. International Journal of Engineering, Business and Enterprise Applications, 4, 108-112.

[21] Verlinden, P., Swanson, R., Sinaton, R., Crane, R., Tiford, C., Perkins, J. and Garrision, K. (1993) High-Efficiency, Point-Contact Silicon Solar Cells for Fresnel Lens Concentrator Modules. Conference Record of the Twenty Third IEEE Photovoltaic Specialists Conference, Louisville, 10-14 May 1993, 58-64. https://doi.org/10.1109/PVSC.1993.347079

[22] Ray, K., Mullen, E. and Trumble, T. (1993) Results from the High Efficiency Solar Panel Experiment Flown on CREES. IEEE Transactions on Nuclear Science, 40, 1505-1511. https://doi.org/10.1109/23.273512

[23] Rainvilleand, E. and Bedient, P. (1974) Elementary Differential Equation. 5th Edition, Macmilla Publishing Co., New York.

[24] El-Adawi, M.K. (2019) Prediction of Symmetrical and Asymmetrical of D Global Solar Irradiance Distribution-New Approach. Optical and Photo Journal, 9, 15-24. https://doi.org/10.4236/opj.2019.92003

[25] Duffiee, J. and Beckman, W. (1974) Solar Energy Thermal Processes. Wiley, Interscince, New York.

[26] Mustafa, S.S. (2019) The Performance and Efficiency of Flat Plate Collectors with Different Absorbers and Different Convection Heat Loss Levels. Material Science Research India, 16, 261-270. https://doi.org/10.13005/msri/160309

[27] Ravindra, N. and Srivastava, V. (1979) Temperature Dependence of the Energy Gap in Semiconductors. Journal of Physics and chemistry of Solids, 40, 791-793. https://doi.org/10.1016/0022-3697(79)90162-8

[28] Tiwari, G. and Suneja, S. (1997) Solar Thermal Engineering Systems. Narosa Publishing House, London.

[29] Leung, C. (1980) The Fluctuation of Solar Irradiance in Hong Kong. Solar Energy, 25, 485-494. https://doi.org/10.1016/0038-092X(80)90080-8

[30] Battacharyya, A. and Streetman, B. (1981) Dynamics of Pulsed $\mathrm{CO}_{2}$ Laser Annealing of Silicon. Journal of Physics D: Applied Physics, 14, 67-72. https://doi.org/10.1088/0022-3727/14/5/002

[31] El-Adawi, M.K., El-Nhass, M.M., Farid, A.S., Shalaby, S.A. and Hegab, N.A. (2019) The Intensity Dependency of the Series Resistance and Other Parameters of a Photovoltaic Silicon Solar Cell in Relation to Its Performance. Journal of Applied Research, 9, 63-66.

[32] General Organization for Housing, Building and planning Research Center (1980) Data on the Hourly Daily Global Solar Irradiance on a Horizontal Surface. Cairo. 